\title{
KOMPARASI MUSIK GUBANG DAN MUSIK GONDANG PORANG DALAM IRINGAN BAPUNCAK DI KOTA TANJUNGBALAI ASAHAN
}

\author{
Melan Sari \\ Prodi Pendidikan Musik
}

\begin{abstract}
Purpose of this study is to investigate the formation of existence Gubang music, and Gondang Porang music in accompaniment Bapuncak in Tanjungbalai Asahan, form music Gubang in accompaniment Bapuncak, form Gondang Porang music in accompaniment Bapuncak, with comparation from form Gubang music and form Gondang Porang music in accompaniment Bapuncak in Kota Tanjungbalai Asahan
\end{abstract}

The theory used in this research include music theory, analisys form music theory,comparation Gubang music, Gondang Porang music, and Bapuncak as base in study for get output is want.

This research make in Tanjungbalai Asahan City. The population and sample is: recorded file of Gubang music and Gondang Porang music, music instructor, four Gondang Porang music players, traditional self players, and sample is: recorded file of Gubang music and Gondang Porang music, music instructor all at once traditional self instructor, four Gondang Porang music players. The method used in this research isqualitative descriptive. Data collection techniques used were library research, laboratory work, field observations, interviews, and documentation.Processing techniques and data analysis using qualitative descriptive research type.

According to the research results, Gubang music have many fungtion from last period, however become accompaniment for entertainment at now period. Existence Gondang Porang music from last period until now stil like accompaniment Bapuncak. Form Gubang music is two motif ml and $m 2$, no have frase and sentence, because all of it is repeating rithym. Form Gondang Porang music is two sentence, that is sentence $A$ with a like question frase and $x$ like answer frase. From motif $A$ have two motif, that is $m 1$ and $m 2$. In Sentence $B$ found two frase that is $b$ like question frase and $y$ as answer frase, be found two motif at sentence $B$ that is $m 3$ and $m 4$.

Keyword: Gubang music, Gondang Porang, Accompaniment, Bapuncak 


\section{PENDAHULUAN}

Kebudayaan merupakan pengetahuan, ide dan hasil cipta masyarakat, hal ini berarti kebudayaan itu beragam jenisnya. Keragaman budaya ini terjadi karena banyaknya etnis atau suku yang dimiliki oleh masyarakat itu sendiri. Masyarakat Indonesia sangat dikenal dengan keragaman suku bangsanya, dari Sabang sampai Merauke begitu banyak terdapat suku beserta ragam tradisi seperti tradisi yang ada pada suku Jawa, suku Batak, suku Melayu, suku Dayak dan sebagainya.

Beragam jenis suku/ etnis dan tradisi dari keunikan masyarakat Indonesia itu sangat berkaitan erat dengan keberadaan musik-musik daerah yang dikembangkan disetiap daerah di Nusantara. Di Sumatera Utara ada berbagai jenis musik etnis dan instrumentnya yang masih digunakan dalam memenuhi kebutuhan acara adat. Musik etnik dan instrument tradisional yang ada di Sumatera Utara mengandung makna tersendiri dan memiliki karakteristik yang berbeda disetiap daerahnya, seperti halnya Senandung Bilah yang dimiliki masyarakat melayu Rantau Prapat, Gordang Sembilan dari suku Mandailing, Gondang Sabagunan dari suku Batak, Musik Gubang, Gondang Porang dari suku Melayu Pesisir di Kota Tanjungbalai Asahan serta masih banyak lagi.

Tidak sedikit masyarakat dari daerah lain yang tinggal dan menetap di Kota Tanjungbalai. Hal ini menyebabkan Kota Tanjungbalai memiliki keragaman budaya dan kesenian tradisional, seperti "Bapuncak" (Pencak silat) yang ada di kota Tanjungbalai Asahan ini menjadi kesenian lokal dan diiringi oleh musik khas masyarakat Melayu Kota Tanjungbalai Asahan.

Kegiatan Bapuncak atau Pencak silat ini selain menjadi sarana bela diri, juga sering digunakan sebagai hiburan tarian pembukaan dan penyambutan dalam menerima pengantin laki-laki yang akan tiba kepelaminan. Namun walau begitu prinsip utamanya tetaplah silat dan bela diri, dahulunya dikeranakan ketika sering berlatih banyak orang yang suka datang dan melihat proses latihan maka muncul ide untuk mengiringi 
Bapuncak dengan iringan musik. Musik Gubang dan Gondang Porang, adalah musik yang sangat identik dengan Pencak Silat di Tanjungbalai Asahan, karena Musik Gubang dan Gondang Porang memiliki struktur ritme dan melodi yang rancak.

Sama halnya dengan Musik Gubang, Gondang Porang juga merupakan musik pengiring Pencak silat yang di dipadukan dari musik Melayu dan musik Minangkabau. Kombinasi ini sangat efektif, sehingga menjadi suatu musik baru yang terdengar berbeda. Hal ini terjadi karena perpindahan beberapa orang atau kelompok dari suku/ etnis Minangkabau yang berpindah dan bermukim di Kota Tanjungbalai Asahan serta menetap dan membangun perguruan Pencak silat sehingga terjadilah perpaduan musik yang dinamakan dengan musik pengiring Gondang Porang.

Terciptanya musik ini tidak terlepas dari kebutuhan masyarakat yang gemar menyaksikan penampilan para penari Pencak silat. Hal ini pula lah yang mendorong para pemain musik untuk memberikan hal berbeda pada gerakan tari serta warna baru dalam musik yang mengiri Pencak silat.

Para peserta atau murid yang ada di sanggar pencak silat yang ada di Kota Tanjungbalai Asahan biasanya lebih memilih menjadi pemain silat dari pada pemain musik baik itu Musik Gubang atau Gondang Porang, karena proses belajar bela diri Pencak silat lebih sederhana dibandingkan dengan proses belajar bermain musik.

Sangat dikhawatirkan keberlangsungan Musik Gubang dan Gondang Porang dapat terlupakan seiring dengan perkembangan zaman. Karena pada dasarnya tidak semua kesenian rakyat ditulis atau dicatat dan menjadi sebuah dokumen untuk mempermudah dalam mengingat dan menghindari sesuatu yang mungkin hilang.

Perbedaan yang ada pada atraksi Bapuncak yang diiringi Musik Gondang Porang memiliki perbedaan dengan Bapuncak yang diiringi Musik Gubang, yaitu terlihat pada bentuk musik, ritme, tempo, dan gerakan yang dihasilkan. 


\section{Toeri Musik}

Musik merupakan nyanyian suara hati/ ungkapan kesedihan perasaan jiwa seseorang terhadap apa yang di alami, baik itu keadaan suka maupun duka yang dikeluarkan secara teratur dalam bentuk bahasa bunyi. Apabila cetusan isi hati dikeluarkan lewat mulut manusia disebut musik vokal, dan apabila lewat alat-alat musik disebut dengan musik instrumental. Oleh karena itu, pengertian musik sangat universal tergantung bagaimana orang memainkan serta menikmatinya. Dari penjelasan diatas musik terbagi atas tiga unsur penting, beberapa unsur tersebut juga terdapat di dalam Musik Gubang dan Gondang Porang juga diataranya sebagai berikut : Ritme, Melodi, dan Harmoni.

\section{Teori Analisa Bentuk Musik}

Bagi musisi baik pencipta, penyanyi, pendengar maupun pengamat pengetahuan akan bentuk analisis musik dirasa sangat perlu karena pada hakikatnya musik bukanlah sekadar rakitan nada, ritme, tempo, dinamik, warna suara, dan unsur-unsur musik lainnya. Secara lebih mendasar musik adalah perwujudan ide-ide atau emosi. Pengertian tersebut akan mengandung konsekuensi bahwa musik sebenarnya mempunyai makna. Dengan mengetahui tahaptahap proses penciptaan serta analisis musik maka para musisi akan menghasilkan nilai audio serta menumbuhkan sikap yang matang.

Dari pemaparan yang ada mengenai teori analisa bentuk musik, diketahui ada beberapa teori analisa bentuk musik yang terdiri atas tiga bagian yaitu: Frase, Motif, dan Kalimat.

\section{Komparasi}

Komparasi atau yang lebih dikenal dengan komparatif ialah: Berkenaan atau berdasarkan perbandingan dan arti penelitian yang membahas tentang perbandingan. Dimana hal ini berarti Komparasi Musik Gubang dan Musik Gondang Porang dalam Iringan Bapuncak membahas mengenai perbandingan apa dan 
bagaimana kedua musik ini ketika mengiringi Bapuncak.

\section{Musik Gubang}

Musik Gubang pada mulanya dimainkan dengan alat musik yang sederhana, motif yang sederhana serta ritme yang juga sederhana dan mudah untuk diingat serta dipelajari secara spontan. Namun seiring berkembangnya pengetahuan musik maka bertambah pula alat musik yang menjadi instrument pengiring dalam memainkan Musik Gubang.

Musik Gubang merupakan musik sakral yang dahulunya digunakan sebagai musik pengiring kegiatan "Mambang" yang biasa dikenal dengan istilah Jamu laut, iringan musik para nelayan saat menyanyikan Senandung yang diberi judul Bertelur Kau Sinangin dipinggir pantai ketika akan pergi kelaut.

\section{Gondang Porang}

Bentuk musik Gondang Porang yang ada di Asahan dimainkan menggunakan beberapa alat musik yang disebut dengan Gondang atau Gendang. Penyebutan nama alat musik di Kota Tanjungbalai tetap menggunakan dialek khas Tanjungbalai. Dimana huruf-huruf vocal seperti A-I-U-E bisa berubah menjadi O. Seperti dalam penyebutan alat musik Gendang, maka akan berubah menjadi Gondang, sehingga jadilah musik ini dinamai dengan Gondang Porang.

Gendang adalah alat musik yang banyak ditemukan di Indonesia, alat musik ini merupakan alat musik membrafon yang banyak digunakan sebagai alat musik/ instrumen musik dalam tradisi

\section{Bapuncak (Pencak silat)}

Bapuncak (Pencak silat) atau silat (berkelahi dengan menggunakan teknik pertahanan diri) ialah seni bela diri Asia yang berakar dari budaya Melayu. Seni bela diri ini secara luas dikenal di Indonesia, Malaysia, Brunei, dan Singapura tapi bisa pula ditemukan dalam berbagai variasi di berbagai negara sesuai dengan penyebaran suku Melayu, seperti di Filipina Selatan dan Thailand Selatan. Berkat peranan para pelatih asal Indonesia, 
saat ini Vietnam juga telah memiliki pesilat-pesilat yang tangguh.

Pencak Silat merupakan budaya yang dapat ditemukan dibeberapa suku/ etnis, yang penyebutannya berbeda-beda pada setiap daerah, di daerah Labuhan Batu dan sekitarnya masyarakat menyebut Pencak Silat dengan kata "Marmuccak", di Kota Tanjungbalai Asahan masyarakat menyebutnya dengan "Bapuncak" dan masih banyak sebutan lain sesuai dengan bahasa dan logat dari daerah itu sendiri. Pencak silat merupakan gerakan-gerakan bela diri yang digunakan oleh bangsa Indonesia dalam perlawanannya pada bangsa penjajah.

Disetiap daerah memiliki beberapa jenis gerakan silat yang berbeda, akan tetapi tidak terlepas dari gerakan dasar silatnya. Penampilannya juga diiringi dengan musik iringan yang berbeda disetiap daerah.

\section{Observasi Lapangan}

Tujuan observasi adalah untuk mempelajari dan memahami secara intensif pelaksanaan penelitian yang dilakukan dengan pengamat, agar peneliti dapat mengamati serta memahami perbandingan atau Komparasi Musik Gubang dan Gondang Porang yang diteliti secara langsung.

\section{Wawancara}

Wawancara merupakan tehnik yang sangat tepat digunakan dalam penelitian kualitatif sehingga sebagai modal awal dalam wawancara dapat diketahui yaitu sebagai berikut:

a. Persiapan

b. Wawancara, teknik bertanya, dan pencatatan hasil wawancara.

Dalam wawancara penulis terlebih dahulu memberi, dan memilih.

c. Menentukan para informan (objek wawancara yang dianggap mengetahui dibidangnya).

\section{Dokumentasi}

Dokumentasi merupakan kegiatan mencari atau mengumpulkan data mengenai hal- 
hal atau variabel yang berupa catatan, transkip, gambaran, buku, surat kabar, majalah, prasasti, notulen rapat dan sebagainya.

\section{Kerja Laboratorium}

Melakukan suatu penelitian dan bermaksud untuk menuliskan apa yang telah diteliti, membutuhkan suatu ruang/ tempat dan suatu tehnik atau cara untuk dapat menyelesaikan tugas tersebut dimana pada penelitian ini akan dilakukan dalam kerja laboratorium.

Hal ini berarti kerja laboratorium adalah suatu usaha yang dilakukan didalam suatu tempat yang bertujuan untuk melihat dan merangkai hasil penelitian agar hasil yang didapatkan menjadi lebih baik. penelitian yang dilakukan ini untuk mengetahui spesifikasi penelitian yang akan dilakukan. Kerja laboratorium yang akan dilakukan dari judul Komparasi Bentuk Musik
Gubang Dan Bentuk Musik Gondang Porang Dalam Iringan Bapuncak Di Kota Tanjungbalai Asahan yaitu: Mengetahui bentuk musik Gubang dan bentuk musik Gondang Porang dalam mengiringi Bapuncak di kota Tanjungbalai Asahan.

\section{ISI}

Musik Gubang merupakan musik yang dimainkan dengan alat musik ritmis, dan dimainkan secara berulang-ulang. Hal ini menyebabkan tidak terdapat ritem pembawa melodi didalam partitur musik ini. Tidak ada bagian bentuk lagu serta kalimat dan frase, hanya terdapat dua motif pada musik ini yaitu: Motif 1 (m1) yaitu pada bar 14 dan pengulangan harafiah pada bar 60-63 secara terbalik sebagai $\mathrm{ml}$ '. Motif 2 (m2) yaitu pada bar 5-6 dan diulang kembali dari bar 7-59 secara harafiah sebagai m2'.

Musik Gondang Porang memiliki dua bagian lagu yaitu bagian $A$ dan $B$. Kalimat $A$ pada musik Gondang Porang diatas dimulai dari bar 1-4, selanjutnya 
terdapat pengulangan pada bar 17-19

. Pada kalimat $A$ terdapat dua frase, frase pertanyaan (a) dan frase jawaban $(x)$. frase $a$ dimulai dari bar 2-4, frase $x$ dimulai dari bar 5-9. Selanjutnya pada pengulangan kalimat $A$ frase $a$ dimulai dari bar 17-19, dan frase $x$ dimulai dari bar 20-24. Pada kalimat $A$ terdapat motif 1 (m1), dan motif 2 (m2), pada motif 1 (m1) terdapat pembalikan motif bebas (m1') dan pengulangan motif m1' dengan pembalikan pemerkecilan $\mathrm{ml}$ " yang didalam musik melayu dikatakan sebagai cengkok. Pada bar 1-4 merupakan bagian dari $\mathrm{m} 1, \mathrm{~m} 1$ ' dan $\mathrm{ml}$ ". Selanjutnya pengulangan harafiah pada kalimat $A \mathrm{~m} 1, \mathrm{ml}$ ' dan $\mathrm{m} 1$ ", dimulai dari bar 17-19. Kemudian pada bagian ending bar 32-33 terdiri dari motif $\mathrm{m} 1$ ' dan $\mathrm{m} 1$ '. Motif 2 (m2) terdapat pada bar 5-9 dimana terdapat m2' pada bar 6-8 pengulangan motif secara harafiah dan bar 9 sebagai penyambung kalimat pertama dengan kalimat kedua. Setelah itu pada $\mathrm{m} 2$ terjadi pengulangan harafiah pada bar 20 , serta m2' pada bar 21-24. Kalimat $B$ pada musik Gondang Porang diatas dimulai dari 10-12 selanjutnya terdapat pengulangan dari kalimat $B$ dimulai dari bar 25-31.

Pada kalimat $B$ terdapat dua frase, frase pertanyaan $(b)$ dan frase jawaban $(y)$. frase $b$ dimulai dari bar 10-12, frase $y$ dimulai dari bar 13-16. Selanjutnya pada pengulangan kalimat $B$, frase $b$ dimulai dari bar 25-27 dan frase $y$ dari bar 28-31. Pada kalimat $B$ terdapat dua motif yaitu motif $3(\mathrm{~m} 3)$ dan motif $4(\mathrm{~m} 4)$. Motif 3 (m3) terdapat pada bar 10 dan motif 4 (m4) terdapat pada bar 11 dan pengulangan harafiah pada bar 12. Motif m4' pada bar 13 dengan sekuens naik pengembangan elongated, bar 14 merupangan m4 pengulangan harafiah serta bar 15 merupakan pengulangan dari $\mathrm{m} 4$ ' dan bar 16 pengulangan harafiah dari m4. Selanjutnya pengulangan harafiah kalimat $B$ pada bar 25-31, yaitu motif 3 (m3) dan motif 4 (m4). Motif 3 (m3) terdapat pada bar 25 dan motif $4(\mathrm{~m} 4)$ terdapat pada bar 26 dan pengulangan harafiah pada bar 27. Motif $\mathrm{m} 4$ ' pada bar 28 dengan sekuens naik pengembangan elongated, bar 29 merupangan m4 pengulangan harafiah serta bar 30 
merupakan pengulangan dari $\mathrm{m} 4$ ' dan bar 31 pengulangan harafiah dari $\mathrm{m} 4$.

\section{Komparasi Musik Gubang} dan Bentuk Musik Gondang Porang adalah : Musik Gubang dimainkan dengan tiga alat musik yaitu Gendang Induk/ Rebana, Gendang Patam-patam dan Tawak-tawak/ Gong. Terdiri dari ritem sehingga tidak terdapat frase dan kalimat didalamnya, dikarenakan hanya ada dua motif Motif 1 (m1) yaitu pada bar 1-4 dan pengulangan harafiah pada bar 60-63 secara terbalik sebagai $\mathrm{m} 1$ '. Motif $2(\mathrm{~m} 2)$ yaitu pada bar 5-6 dan diulang kembali dari bar 7-59 secara harafiah sebagai m2'. Sedangkan Gondang Porang dimainkan dengan tiga alat musik yaitu: Gendang Patam-patam, Tawak-tawak/ Gong dan Sarune sebagai pembawa melodi. Sehingga pada musik Gondang Porang terdapat kalimat $A$ yang terdiri dari frase pertanyaan $a$ dan frase jawaban $x$ kemudian pada kalimat $B$ terdiri atas frase pertanyaan $b$ dan frase jawaban y. musik Gondang Porang terdiri atas empat motif yaitu: $\mathrm{m} 1$ dengan $\mathrm{m} 1$ ' dan $\mathrm{m} 1$ ', $\mathrm{m} 2$ terdiri dari $\mathrm{m} 2$ dan $\mathrm{m} 2$ ', $\mathrm{m} 3$, dan $\mathrm{m} 4$ terdiri dari $\mathrm{m} 4$ dan $\mathrm{m} 4$ '.

\section{PENUTUP}

Berdasarkan hasil penelitian tentang Komparasi bentuk Musik Gubang dan bentuk musik Gondang Porang dapat ditarik kesimpulan bahwa Musik Gubang dan musik Gondang Porang memiliki komparasi yang signifikan. Walaupun keduanya memili fungsi yang sama sebagai pengiring pencak silat, akan tetapi apabila ditinjau dari segi bentuk musik akan terlihat perbedaan dari keduanya. Pada Musik Gubang tidak terdapat frase dan kalimat musik, hanya ritem yang di ulang-ulang menjadi bagian musik dan terdiri dari dua motif yaitu $\mathrm{m} 1$ dan $\mathrm{m} 2$.

\section{Pada musik Gondang Porang} memiliki ritme, melodi dan harmoni, sehingga pada bentuk musik dapat diketahui musik Gondang Porang terdiri dari dua kalimat yaitu $A$ dan $B$ bagian $A$ memiliki frase pertanyaan yaitu $a$ dan frase jawaban $x$. Pada kalimat $B$ terdiri dari frase pertanyaan $b$ dan frase jawaban $y$. motif pada musik Gondang Porang 
diketahui ada 4 motif, yaitu $\mathrm{m} 1, \mathrm{~m} 2$, m3, dan m4.

\section{DAFTAR PUSTAKA}

Ary, D, Jacob, L. C, \& Razavieh. A. Tanpa Tahun. Pengantar Penelitian Pendidikan. Terjemahan Arief Furchan. 1982. Surabaya. Usaha Nasional.

Banoe, Pono. 2003. Kamus musik. Yogyakarta: kasinus

Budilinggono, I. 1993. Bentuk dan Analisis Musik. Jakarta: Departemen Pendidikan Dan Kebudayaan.

Bungin, Burhan. 2008. Penelitian Kualitatif. Jakarta: Kencana

Daliman A. 2012. Manusia Dan Sejarah. Yogyakarta: Ombak.

Fathoni, Abdurrahmat. 2006. Metodologi Penelitian Dan Teknik Penyusunan Skripsi. Jakarta: PT. Asdi Mahasatya.

Hadeli. 2006. Metode Penelitian Kependidikan. Padang: Quantum Teaching.

Hariwijaya. 2008. Metode dan Tehnik Penulisan Skripsi. Yogyakarta: Elematera Publishing.

Harahap, Muhammad Faisal. 2011. Perbandingan Tari Gubang Di Kota Tanjungbalai Dengan Tari Gubang Di
Medan. Medan: Skripsi S1 Unimed.

Hasibuan, Melayu S. P. 2006. Manajemen Sumber Daya Manusia. Edisi Revisi I. Jakarta: Bumi Aksara.

Hidayat. 2014. Teori Kebudayaan. Medan

Hidayat, Azis Alimut. 2007. Metode Penelitian dan tehnik Analisis Data. Jakarta: Salemba Medika.

Idrus, Muhammad. 2009. Metode Penelitian Ilmu Sosial. Jakarta : Erlangga

Ikbar, Yanuar. 2013. Metode Penelitian Sosial Kualitatif. Bandung: $\quad$ PT.Refika Aditama.

Iskandar, Atok M. 1992. Pencak Silat. Medan: Universitas STOK Bina Guna.

Maryaeni. 2005. Metode Penelitian Kebudayaan. Bandung : Bumi Aksara.

Miles, M. B. 2005. Analisis Data Kualitatif. Jakarta: Raja Grafindo Persada.

Muchtar. H. 2010. Bimbingan Skripsi, Tesis Dan Artikel Ilmiah, Jambi: Gaung Persada Press.

Naburko, Cholid. 2009. Metodologi Penelitian. Jakarta: Bumi Aksara.

Nugraha R. Adrian. 2010. Mengenal Aneka Cabang Olahraga. 
Bekasi: PT. Cahaya Pustaka Raga.

Nuhriansyah. 2013. Komposisi Musik Iringan Silat Gondang Porang Di Sanggar Silat Keluarga Jaya Lintau Kota Tanjung Balai. Medan: Skripsi S1 Unimed.

Satria, Harry. 2013. Tinjauan Varian Ritme Musik Gubang di Kota Tanjung Balai. Medan: Skripsi S1 Unimed.

Sedarmayanti dan Hidayat. 2011. Metode Penelitian Kebudayaan. Jakarta: Bumi Aksara.

Silalahi, Ulber. 2012. Metode Penelitian Sosial. Jakarta

Silitonga, Pita Hotma Dameria. 2014. Teori musik. Medan: Unimed Prees.

Situmorang, Jaulahan. 1992. Penuntun Adat Praktis. Pematang Siantar.

Soeharto. 2004. Musik Dalam Mencerdaskan Anak. Jakarta: Cakrawala.

Stanley, S. 2009. The Grove Concise Dictionary Of Music. Oxford University Press.

Sugiyono. 2008. Metodologi Penelitian Pendidikan. Bandung : Alfabeta
Sukardi. 2003. Metode Penelitian. Bandung: Alfabeta.

Supranto. 2004. Memahami Penelitian Kualitatif. Bandung : Alfabeta.

Suryono. 2005. Pedoman Penulisan Karya Ilmiah (Proposal, Skripsi, Tesis) dan Mempersiapkan Diri menjadi Penulis Artikel Ilmiah. Jakarta : Pranada.

Sutioso. 2006. Komparasi merupakan perbandingan. Jakarta : Cakrawala

Tharisna, Rizky. 2014. Komparasi Pola Permainan Cello Dalam Suite No. 1 Prelude J.S Bach Versi Pierre Fournier Dengan Steven Sharp Nelson. Medan: Skripsi S1 Unimed.

Tanjung dan Ardial. 2005. Pedoman Penulisan Karya Ilmiah (Proposal, Skripsi, Tesis) dan Mempersiapkan Diri menjadi Penulis Artikel Ilmiah. Jakarta: Kencana Prenada Media Group.

Yustana, Andi. 2010. Instrumen Musik. Bandung: Alfabeta

http://cvrahmat.blogspot.com/2011/0 4/pengertianlaboratorium.html Senin 22Juni- 2015, 11:25 Wib) 